\title{
Citation:
}

O'Kelly B.C. 2005. Mechanical properties of dewatered sewage sludge. Waste Management, Vol. 25, No. 1, 47- 52.

\section{MECHANICAL PROPERTIES OF DEWATERED SEWAGE SLUDGE}

Brendan C. O'Kelly ${ }^{1}$

BE, MEngSc, PhD, CEng, MICE, MIEI

Department of Civil, Structural \& Environmental Engineering University of Dublin, Trinity College, Dublin 2, IRELAND

formerly Scott Wilson Consulting Engineers, UK

First submission: 10 September 2003

Resubmitted: 21 June 2004

1 e-mail: bokelly@tcd.ie $\quad$ Tel. +3531608 2387

Fax. +353 16773072 


\section{ABSTRACT}

The mechanical properties of dewatered, anaerobically digested sewage sludge were determined from soil laboratory tests. The sludge material is largely composed of organic clay sized-particles, a sizable fraction of which is in an active state of biological digestion which can continue over many years under field conditions. Moderately digested sludge material was found to have a typical specific gravity of solids value of 1.55 , and loss on ignition (LOI) value of $70 \%$ dry mass. Strongly digested sludge, produced by digesting the liquid sludge further at $35^{\circ} \mathrm{C}$ in the laboratory, was found to have a lower LOI value of $55 \%$ dry mass, and a higher specific gravity of solids value of about 1.72 . The maximum dry density of 0.56 tonne $/ \mathrm{m}^{3}$ for the dried sludge material was produced using standard Proctor compaction at roughly $85 \%$ moisture content ( $54 \%$ solids content).

Air-dried, compacted sludge material was tested in quick-undrained, triaxial compression and vane shear. Undrained shear strength-moisture content plots are presented. Shear strength values measured in triaxial compression and vane shear were consistent. The effective angle of shearing resistance $\left(\phi^{\prime}\right)$ was determined from consolidated-undrained, triaxial compression tests on pasteurized, normally consolidated samples of the sludge material. The mechanical properties of the sludge material changed with the level of sludge digestion. The $\phi^{\prime}$ value increased from $32^{\circ}$ for moderately digested sludge, to $37^{\circ}$ for strongly digested sludge. The effective cohesion of the sludge material remained zero throughout.

The shrinkage, swelling and adhesion properties of the sludge material were also studied. Significant shrinkage occurred as the compacted material dried. The sludge material lost its adhesion below about $95 \%$ moisture content (51\% solids content). Re-hydration of the dry material caused the bulk volume to double.

Keywords: sewage sludge, mechanical properties, shear strength, landfilling 


\section{INTRODUCTION}

Sewage sludge is the slurry byproduct of wastewater treatment processes. More stringent controls on the quality of wastewater discharges are giving rise to ever increasing volumes of sewage sludge which must be safely disposed. One of the principal means of disposal is to landfill. The sludge material is usually mixing with other solid waste in municipal landfills. Sometimes the sludge material is disposed alone at dedicated monofill sites. For example, Russell (1992) reported one such monofill which was $25 \mathrm{~m}$ in height. The sludge material must be adequately dewatered for efficient disposal and to provide an adequate factor of safety against instability of the landfill slopes. The effects of ongoing biological digestion on the shear strength properties of the sludge material must also be considered when determining the long-term factor of safety against slope instability.

Current knowledge of the mechanical properties, in particular the shear strength properties, of dewatered sewage sludge is limited. In water treatment literature, the shear strength of the sludge material is often estimated from its solids content (SC) value, defined as the ratio of the dry mass of the solid particles to the bulk sludge mass, given as a percentage. In practice, however, shear strength estimates based on the solids content alone are unreliable. Casey (1991), for example, reported that depending on the source of the sludge material and the level of biological treatment, the solids content required for disposal of the sludge material in municipal landfills can vary between $15 \%$ and $50 \%$.

Undrained shear strength-moisture content data were reported by Geuzens \& Dieltjens (1991) for dewatered sewage sludge. Moisture content (w), used in geotechnical literature, is defined as the ratio of the mass of water in the void spaces to the mass of solid particles, given as a percentage. Such data are more useful in determining the actual level of dewatering required prior to landfilling the sludge material. Moisture content and solids content values can be related as follows:

$$
S C=\frac{100}{1+\left(\frac{w}{100}\right)} \quad[\%]
$$

Index, standard Proctor compaction and shear strength tests were conducted on samples of sewage sludge of various consistencies using standard soil laboratory test methods (Head, 1992, 1994, 1998). Biologically active samples were tested at different stages during the digestion process to study the effects of the initial level of treatment at the wastewater plant and ongoing digestion in the landfill on the mechanical properties. Samples of dewatered sewage sludge were obtained from Tullamore Municipal Wastewater Treatment Plant (Tullamore, Ireland), which serves an urban population of approximately 12,000. There was no significant industrial wastewater influent to the plant. The sewage sludge was biologically digested at the treatment plant using the anaerobic, activated sludge method (Metcalf \& Eddy, 1991). The moisture content of the sludge material was reduced to 
roughly $720 \%$ ( $12 \%$ solids content) using belt process dewatering with polyelectrolytes added to the liquid sludge to encourage flocculation of the solid particles.

\section{INDEX PROPERTIES}

The Atterberg limits, particle size distribution, specific gravity of solids, loss on ignition and $\mathrm{pH}$ of the sludge material were measured. Material direct from the wastewater treatment plant had a liquid limit of $315 \%$, a plastic limit of $55 \%$ and a plasticity index of $260 \%$. When wet sieved, roughly $90 \%$ dry mass of the sludge material passed the $425 \mu \mathrm{m}$ sieve indicating that the sludge largely comprised clay-sized particles. Material retained on this sieve comprised some organic fibers, grit particles and shredded plastic. The very high liquid limit and plastic limit values and colloidal activity (the plasticity index to clay fraction ratio) of the sludge are characteristic of calcium montmorillonite clay minerals (Yong \& Warkentin, 1975). Similar liquid limit and plastic limit values were also reported for water treatment plant sludge by Wang et al (1992) and for paper mill sludge by Charlie (1977). Ignition of dry, powdered sludge material at $440^{\circ} \mathrm{C}$ caused a $70 \%$ reduction of the sample dry mass. This loss on ignition (LOI) value is an indirect but fairly accurate measure of the organic content of the sludge material. Based on the Atterberg limits and this LOI value, the sludge material is organic clay of high plasticity according to the Unified Soil Classification System.

The specific gravity of solids value of 1.55 was measured using the small pycnometer method. Kerosene was used instead of distilled water as the fluid in the pycnometers. Otherwise the sludge samples would have continued to slowly decompose during the tests yielding inaccurate results. The specific gravity of solids value of 1.55 is low when compared with inert soils which generally have a value in the range of 2.5 to 2.7 . However, the specific gravity of solids value measured for the sludge material is consistent with the range of 1.4 to 2.1 reported for other sewage sludge by Campbell et al (1978) and the range of 1.41 to 1.83 reported by Skempton \& Petley (1970) for peat with similar LOI values. The $\mathrm{pH}$ value of the leachate was 8.0, which is slightly high for anaerobically digested sewage sludge. These LOI and $\mathrm{pH}$ values for the sludge material indicate that only moderate biological digestion of the sewage sludge occurred at the wastewater treatment plant. Strong digestion would have typically yielded an LOI value in the range $45 \%$ to $55 \%$ and a $\mathrm{pH}$ value in the range 6.6 to 7.4 .

Index tests were also conducted on liquid sludge which was stored outdoors in drums and allowed to digest naturally. Two and a half years after the initial treatment at the wastewater plant, the specific gravity of solids value of the sludge material had increased from 1.55 to 1.63 while the LOI value had reduced significantly from $70 \%$ to $58 \%$. The

latter LOI value indicates that some further biological digestion of the sludge would continue to occur. 


\section{COMPACTION PROPERTIES}

Standard Proctor compaction tests were conducted on air-dried sludge material. The maximum dry density of 0.56 tonne $/ \mathrm{m}^{3}$ was achieved at roughly $85 \%$ moisture content (54\% solids content), the optimum moisture content (OMC) for compaction. The bulk density and dry density values of the compacted sludge material were low but are consistent with the low range of specific gravity of solids values measured. The bulk density increased from about 0.65 tonne $/ \mathrm{m}^{3}$ for dry sludge material, which compacted poorly, to 1.10 tonne $/ \mathrm{m}^{3}$ for sludge material with moisture content values above OMC. More strongly digested sludge material yielded slightly higher bulk density and dry density values which was due to the increase in the specific gravity of solids value with increasing levels of biological digestion.

The shrinkage, swelling and adhesion properties of the sludge material were also studied. The linear shrinkage value of $33 \%$ was measured as the percentage reduction in the length of a bar of the sludge material after it had been oven dried at $105^{\circ} \mathrm{C}$ from the liquid limit condition. The sludge bar was rectangular in cross section and initially $140 \mathrm{~mm}$ long. The swelling potential of the dry sludge material, which is sometimes produced in pellet form after thermal drying processes, was measured as the percentage increase in volume of the dry powered sludge material after it had been pluviated through water (Holtz \& Gibbs, 1956). These free swell tests indicated that dry sludge material has the potential to approximately double in volume when fully re-hydrated.

The lowest moisture content at which moist sludge material adheres to metal tools, often referred to as the sticky limit, was measured at roughly $95 \%$ moisture content (51\% solids content). Sludge handling may prove difficult when the moisture content of the sludge exceeds the sticky limit value since the sludge material will tend to cling to the machine plant. The sticky limit value was measured as the lowest moisture content at which sludge particles adhered to a clean dry spatula, when the spatula was lightly drawn over the surface of a pat of the sludge material.

\section{SHEAR STRENGTH PROPERTIES}

The short-term and long-term shear strength properties of the sludge material were measured in the laboratory. The short-term shear strength, usually referred to as the undrained shear strength, is pertinent to engineering the efficient handling of the sludge material, trafficability at the landfill site and an adequate factor of safety against slope instability during landfill operations. The effective-stress strength properties of the sludge material are used to calculate the factor of safety against instability of the landfill slopes for intermediate and long-term conditions. Moderately and strongly digested sludge was tested to study the effects of biological digestion on the shear strength properties. 


\section{$\underline{\text { Undrained shear strength properties }}$}

The undrained shear strength of the dewatered sludge material was measured using the laboratory vane shear apparatus, with a $12.7 \mathrm{~mm}$ long by $12.7 \mathrm{~mm}$ wide, cruciform vane. The undrained shear strength of the dried, compacted sludge material was measured using both the triaxial compression apparatus and the vane shear apparatus. The sludge material was air-dried in the laboratory to moisture content values above the $85 \%$ OMC value and compacted into a one-liter mould using standard Proctor compactive effort. A set of three $38 \mathrm{~mm}$ diameter, triaxial samples were prepared from each of the Proctor samples. Some of the triaxial samples were air dried to reduce their moisture content below the OMC value before the samples were sheared. This sample preparation method yielded samples whose properties were characteristic of dried sludge material, compacted in the landfill under optimum conditions and allowed to air-dry. Figure 1 shows the bulk density and dry density values of the samples tested in quick-undrained, triaxial compression and vane shear. The compacted sludge material was partially saturated with an air voids content of about 5\%.

An isotropic confining pressure of $100 \mathrm{kPa}$ was applied to the triaxial samples which were then sheared quickly under undrained conditions, at an axial compression rate of $1.6 \%$ strain/minute. The shear stress-axial strain plots shown in Figure 2 are characteristic of normally consolidated clay and indicate that large strains are required to fully mobilize the shear strength of the sludge material. The undrained shear strength-moisture content data summarized in Figure 3 shows the usual behavior of the undrained shear strength increasing exponentially with reducing moisture content. The shear strength values plotted correspond to the shear stress mobilized at $20 \%$ axial strain of the sample. The undrained shear strength measured in triaxial compression was slightly lower than that measured in vane shear although the two data sets are generally consistent. Hence, in practice, quick and reliable shear strength measurements can be made using the vane shear apparatus in order to assess whether the sludge material has been adequately dewatered for landfilling.

\section{Effective-stress strength properties}

The effective stress strength properties of moderately and strongly digested sludge material were determined using consolidated-undrained, triaxial compression tests and with measurement of the pore water pressure response. Samples of moderately digested sludge were obtained direct from the wastewater treatment plant. Cakes of the sludge material were formed by consolidating liquid sludge using the large hydraulic consolidation cell (Head, 1998). Triaxial samples were prepared from the pasteurized sludge cakes.

Strongly digested sludge was produced by digesting liquid sludge further in the laboratory. Two and a half liters of moderately digested sludge ( $720 \%$ moisture content) was poured into the $250 \mathrm{~mm}$ diameter, hydraulic consolidation cell. The consolidation cell was placed in a drying oven and the oven temperature gradually increased to $35^{\circ} \mathrm{C}$, the optimum temperature for mesophilic digestion. The consolidation cell remained in the oven for 21 days with the oven temperature held at $35^{\circ} \mathrm{C}$. Biogas evolved continuously at a rate of about 
0.3 liters biogas per day per liter of liquid sludge. In total, 23.7 liters of biogas evolved and the volume of the liquid sludge sample was approximately halved. The oven temperature was gradually reduced back to laboratory temperature after the 21 days had elapsed. Index tests later confirmed that the sludge material was now strongly digested after this heat treatment. The specific gravity of solids value had increased from 1.55 to 1.72 while the LOI value had reduced from $70 \%$ to $55 \%$.

The liquid sludge remaining in the hydraulic consolidation cell was consolidated onedimensionally under an applied cell pressure of $100 \mathrm{kPa}$ in order to form a sludge cake. The sludge cake was then pasteurized so that the sludge material would remain saturated, permitting accurate measurements of the pore water pressure response during the triaxial compression tests. The consolidation cell was gradually reheated to $80^{\circ} \mathrm{C}$ in the drying oven and the sludge cake, contained in the consolidation cell, was allowed to swell under undrained conditions against the applied confining pressure of $100 \mathrm{kPa}$. After three hours of heating at $80^{\circ} \mathrm{C}$, biogas had stopped evolving from the sludge cake, indicating that pasteurization was complete. The oven temperature was gradually reduced back to laboratory temperature and the consolidation cell dismantled.

Two sets of three triaxial samples were prepared from pasteurized cakes of strongly and moderately digested sludge material. The $38 \mathrm{~mm}$ diameter samples were set up in the triaxial apparatus to facilitate drainage via the radial boundary and one end of the sample, with continuous measurement of the pore water pressure response. Cell confining pressure and sample back pressure increments were applied until a back pressure of $240 \mathrm{kPa}$ was reached. Both sets of samples were then isotropically consolidated until effective confining pressures of $30 \mathrm{kPa}, 60 \mathrm{kPa}$ and $140 \mathrm{kPa}$ were achieved at the end of the consolidation stage. Volumetric strain-time plots recorded for the set of moderately digested samples are shown in Figure 4.

The triaxial samples were sheared under undrained conditions at an axial compression rate of $0.002 \%$ strain/minute which was sufficiently slow to allow all pore water pressures in the sample to equilibrate. Figure 5 shows the effective stress-path plots of $t=1 / 2\left(\sigma_{1}-\sigma_{3}\right)$ against $s^{\prime}=1 / 2\left(\sigma^{\prime}{ }_{1}+\sigma^{\prime}{ }_{3}\right)$ for the set of three moderately digested samples. These stress paths are characteristic of normally consolidated clay. The test results were corrected for the effects of the sample membranes and side drains. The samples were deemed to have failed at $20 \%$ axial strain and the failure line of best fit was drawn through the origin and these set of points (Figure 4). The value of the effective angle of shearing resistance $\left(\phi^{\prime}\right)$ for the moderately digested sludge of $32^{\circ}$ was calculated using Eq. (2). Similarly, a $\phi^{\prime}$ value of $37^{\circ}$ was calculated for the strongly digested sludge material. This range of $\phi^{\prime}$ values is similar to that reported for peat by Andersland et al. (1981). The effective cohesion remained zero, irrespective of the level of biological digestion.

$$
\operatorname{Sin} \phi^{\prime}=\operatorname{Tan} \alpha^{\prime}
$$

where $\alpha^{\prime}=$ the angle of slope of the failure line to the horizontal $s^{\prime}$ axis (Figure 4). 
The ratio of the mobilized shear strength $\left(c_{u}\right)$ to the effective consolidation pressure $\left(\sigma^{\prime}{ }_{c}\right)$ was 1.1 at sample failure. This value equals that predicted for saturated normally consolidated clay using Eq. (3), after Skempton (1957). Similar $c_{\mathrm{u}} / \sigma^{\prime}{ }_{\mathrm{c}}$ values were reported by Andersland et al. (1981) for model organic soils with comparable LOI values.

$$
\frac{c_{u}}{\sigma_{c}^{\prime}}=0.11+(0.0037)(P I)
$$

where $P I=$ the plasticity index $(\%)$.

The effective angle of shearing resistance values of $32^{\circ}$ and $37^{\circ}$ were measured for pasteurized sludge material. However, these values can also be used to determine the longterm factor of safety against instability of landfill slopes constructed using biologically active sludge providing effective biogas control and leachate drainage systems are in place. Biogas which becomes trapped in the landfill body will cause a build up in the pore pressure, which if left unchecked, will cause swelling and potentially lead to slope instability (Russell, 1992). In other instances, further digestion of the landfilled sludge material can be hindered, for example, if industrial waste containing heavy metals were to become mixed with the sludge. Slope stability calculations should therefore be performed using the $\phi$ ' values measured for both moderately and strongly digested sludge material. The long-term factor of safety will be given by the lower of the two factor of safety values calculated. The values of other mechanical properties used in these calculations must relate to the appropriate level of biological digestion.

\section{SUMMARY AND CONCLUSIONS}

The mechanical properties pertinent to the efficient handling and safe landfill disposal of dewatered, sewage sludge were determined from soil laboratory tests. The material tested was an anaerobically digested, sewage sludge which was found to be largely composed of organic clay sized-particles, a sizable fraction of which was still in an active state of biological digestion. However, the rate of digestion was highly dependent on the environment. For example, heating liquid sludge at $35^{\circ} \mathrm{C}$ for 21 days under laboratory conditions produced similar levels of strong digestion as that achieved when the same material, stored outdoors in drums, was allowed to digest naturally at ambient temperature over two and a half years. Strongly digested sludge material was found to have a loss on ignition (LOI) value of about $55 \%$ dry mass, and a specific gravity of solids value of about 1.72. Moderately digested sludge material from the wastewater treatment plant had a lower specific gravity of solids value of 1.55 and a higher LOI value of $70 \%$ dry mass.

The maximum dry density of 0.56 tonne $/ \mathrm{m}^{3}$ for the sludge material was produced using standard Proctor compaction at roughly $85 \%$ moisture content (54\% solids content). The 
density of the compacted material was low in comparison with inert soils but the density values are in line with the range of specific gravity of solids values measured for the sludge material.

Air-dried, compacted sludge material was tested in quick-undrained, triaxial compression and vane shear. The undrained shear strength values measured in triaxial compression and vane shear were consistent. Hence, the vane shear apparatus can be used to quickly assess whether the sludge material has been dewatered sufficiently for landfilling. Undrained shear strength-moisture content plots are presented from which the level of dewatering necessary to facilitate efficient handling of the sludge material, trafficibility at the landfill site and an adequate factor of safety against slope instability for the short-term condition can be determined. The effective stress strength parameters were determined from consolidated-undrained, triaxial compression tests conducted on pasteurized, normally consolidated samples of the sludge material. The mechanical properties of the sludge material changed with the level of sludge digestion. The value of the effective angle of shearing resistance $\left(\phi^{\prime}\right)$ increased from $32^{\circ}$ for moderate digestion, to $37^{\circ}$ for strong digestion. The effective cohesion of the sludge material remained zero throughout. Providing effective biogas control and leachate drainage systems are in place, the factors of safety against instability of the landfill slopes for the intermediate and long-term conditions can be assessed using these $\phi^{\prime}$ values.

The shrinkage, swelling and adhesion properties of the sludge material were also studied. Significant shrinkage occurred as the compacted sludge material dried. The sludge material lost its adhesion below about $95 \%$ moisture content ( $51 \%$ solids content). When the dry sludge material was full re-hydration, the bulk volume roughly doubled.

\section{REFERENCES}

Andersland O.B., Khattak A.S. \& Al-Khafaji A.W.N., 1981. Effect of organic material on soil shear strength. In Laboratory shear strength of soil (eds Yong R.N. \& Townsend F.C., ASTM STP 740, 226-242. American Society for Testing and Materials.

Campbell H.W., Rush R.J. \& Tew R., 1978. Sludge dewatering design manual. Research Report No. 72, Ontario Ministry of the Environment.

Casey T.J., 1991. The science and technology of sludge disposal. Proceedings, Seminar on sludge disposal, Institution of Engineers of Ireland, Dublin, 1, 1-24.

Charlie W.A., 1977. Pulp and paper mill solid waste disposal - a review. Proceedings, ASCE Conference on geotechnical practice for disposal of solid waste materials, New York, 1, 71-86. 
Geuzens P. \& Dieltjens W., 1991. Mechanical strength determination of cohesive sludges a Belgian research project on sludge consistency. In Recent developments in sewage sludge processing (eds Colin F., Newman P. J. \& Puolanne Y. J., 4-23. London: Elsevier.

Holtz W.G. \& Gibbs H.J., 1956. Engineering properties of expansive clays. Transactions, American Society of Civil Engineers, 121(1), pp. 641-677.

Head K.H., 1992. Manual of soil laboratory testing, Soil classification and compaction tests, 1, 2nd edn. London: Pentech Press.

Head K.H., 1994. Manual of soil laboratory testing, Permeability, shear strength and compressibility tests, 2, 2nd edn. London: Pentech Press.

Head K.H., 1998. Manual of soil laboratory testing, Effective stress tests, 3, 2nd edn. London: Wiley.

Metcalf \& Eddy, Inc., 1991. Wastewater engineering: treatment, disposal and reuse. 3rd edn. Singapore: McGraw-Hill.

Russell H., 1992. Race to clear sludge landslide. New Civil Engineer, Institution of Civil Engineers, London, $20^{\text {th }}$ Feb, 5.

Skempton A.W., 1957. Discussion on planning and design of the new Hong Kong Airport. Proceedings, Institution of Civil Engineers, London, 7, 305-307.

Skempton A.W. \& Petley, D.J. 1970. Ignition loss and other properties of peats and clays from Avonmouth, King's Lynn and Cranberry Moss. Geotechnique, 20(4), 343-356.

Wang M.C., Hull J.Q., Jao M., Dempsey B.A. \& Cornwell D.A., 1992. Engineering treatment of water treatment sludge. Environmental Engineering, ASCE, 118(6), 848-864.

Yong R.N. \& Warkentin B.P., 1975. Soil properties and behaviour. Netherlands: Elsevier. 


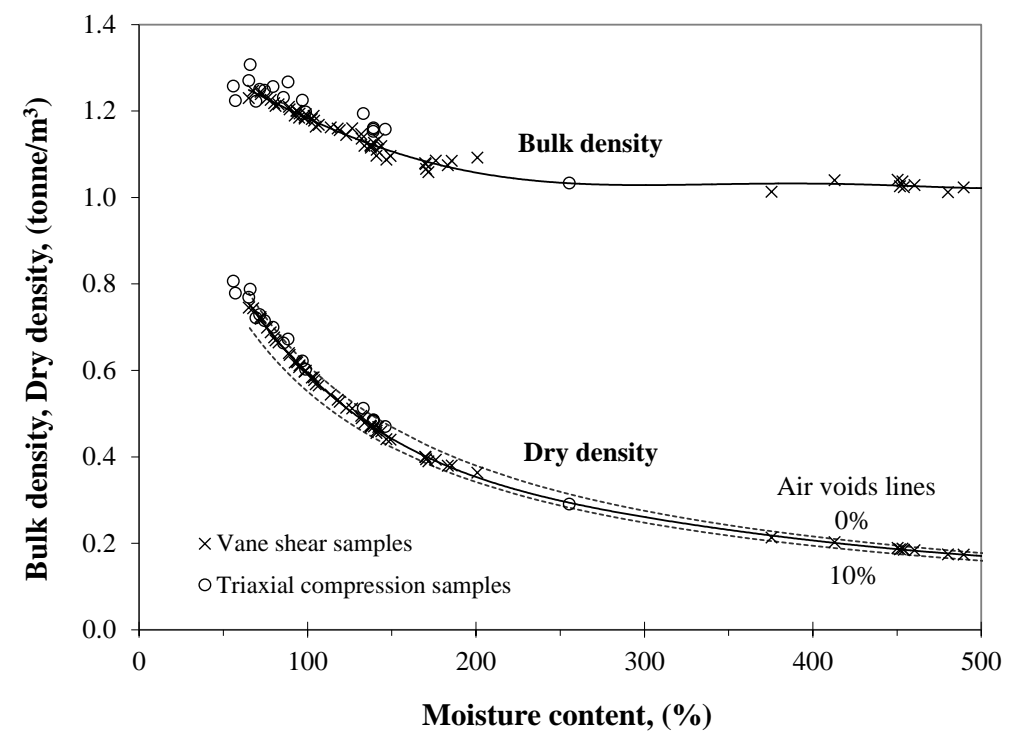

Figure 1: Density vs. moisture content data for undrained shear strength samples.

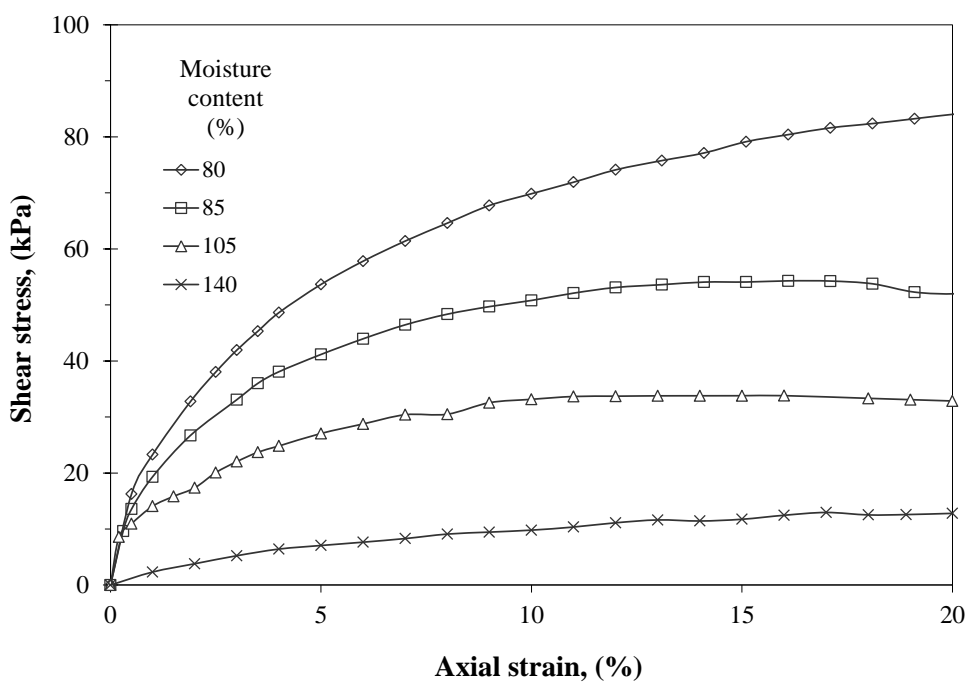

Figure 2: Shear stress vs. axial strain data from quick-undrained, triaxial compression tests. 


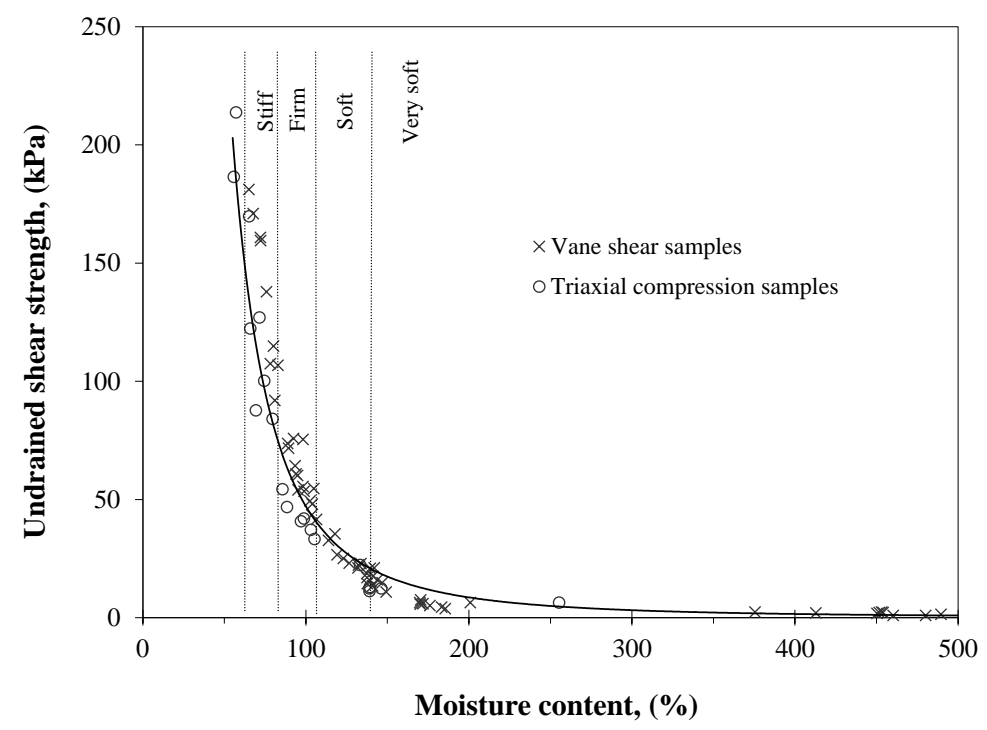

Figure 3: Undrained shear strength vs. moisture content.

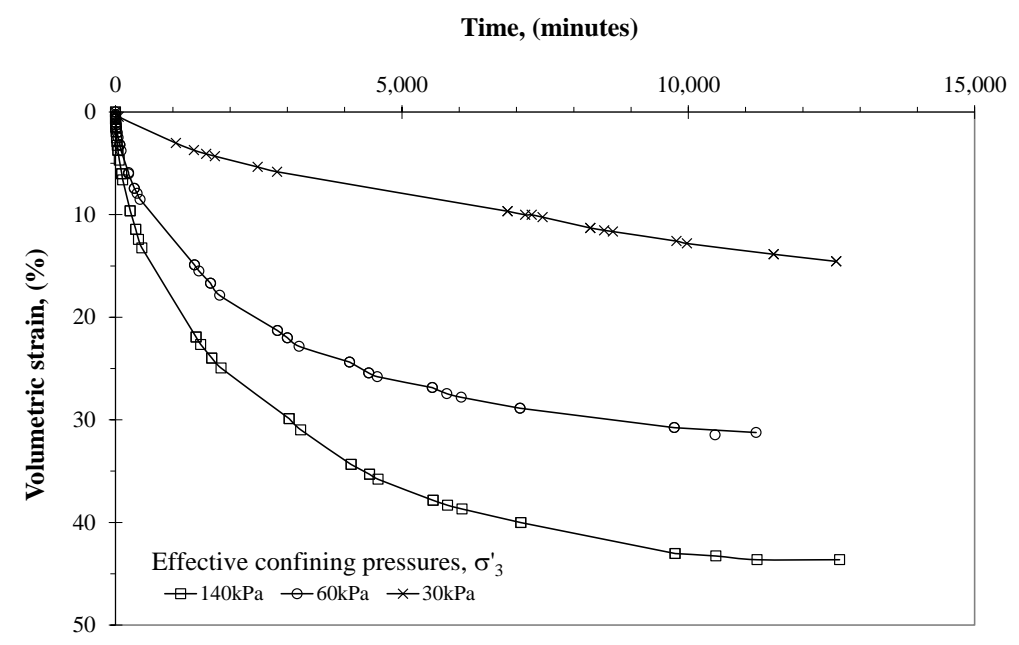

Figure 4: Volumetric strain vs. time data from triaxial consolidation of moderately digested sludge. 


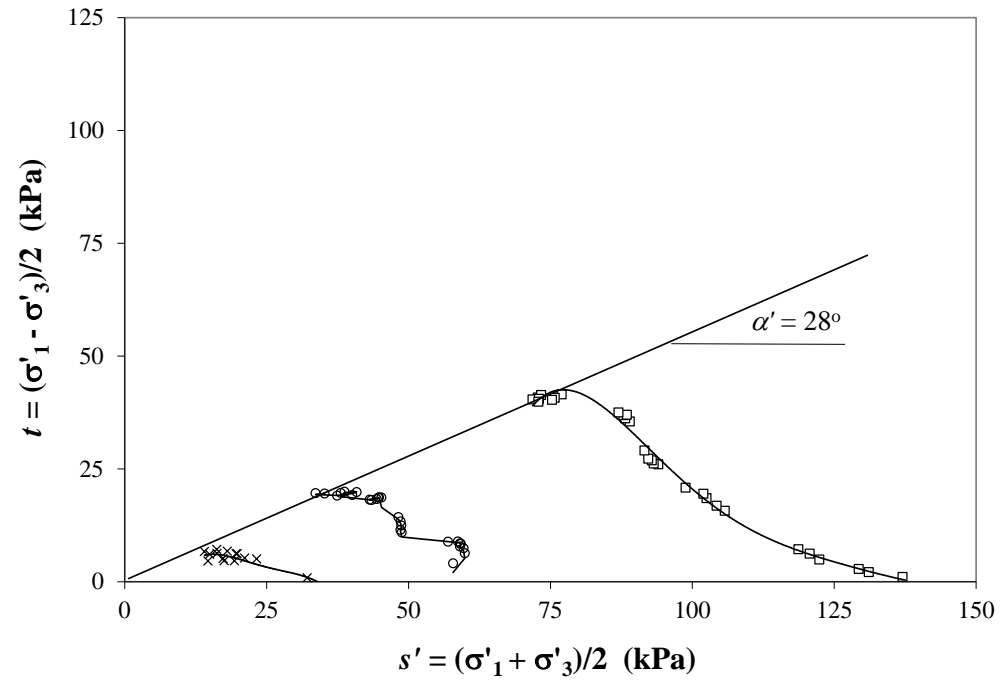

Figure 5: Effective stress-path plots for moderately digested sludge. 